\title{
Commercial Dairy Farming in Jaipur District of Rajasthan: A Case Study
}

\author{
Shirish Sharma* \\ Research Associate, ICAR-NIAP, Delhi, India \\ *Corresponding Author: Shirish Sharma, Research Associate, ICAR-NIAP, Delhi, India.
}

Received: May 16, 2019; Published: June 13, 2019

DOI: $10.31080 /$ ASAG.2019.03.0528

\begin{abstract}
Rajasthan is predominantly an agricultural state with an excellent potential for milk production. Dairy cooperatives have not only provided organized network of milk marketing to the rural households, but also provided the crucial technical inputs like provision of artificial insemination, health services and feed inputs. For the present study Jaipur district was selected purposively because it is second largest milk producer in the state. To select a sample of commercial dairy farms, a complete enumeration of commercial dairy farms in these villages was done. Primary data on various aspects of milk production enterprises were collected from each of the selected dairy units by personal interview method. The average capital investment per farm on sample farms was found to be Rs 14.97 lacs. The total cost of maintenance of crossbred milch cattle on medium category of commercial farms was estimated to be Rs. 405/animal/day. The average milk yield of crossbred milch animals on medium farms was found to be 17 liter/day. The cost of milk production was worked out to be Rs. 23.24/liter. The average yield/milch animal on large farms were found to be 22 liter/day and the cost of milk production was worked out to be Rs 23.63/liter. Returns from the buffaloes on small and medium dairy farms showed that each milch buffalo earned overall net return of Rs 7and Rs 6.65/liter/day which was higher than that of large dairy farms. It may be observed that small category of dairy farms generated a net surplus of Rs 267180 per year whereas the medium dairy farms earned Rs 412085. The large dairy farms earned net profit of Rs. 946445 per year.
\end{abstract}

Keywords: Costs; Dairy farm; Profitability and Returns

\section{Introduction}

India has one of the largest animal husbandry sectors in the world having largest livestock population with 520.6 million head. Globally, livestock population constitutes of, cattle (12.7\%), Buffalo (56.7\%), goat (14.5\%) and sheep (5.9\%) [1]. Livestock are a natural asset for poor that can be liquidated when required. For rural poor livestock are wealth and a sort of insurance substitute during times of crisis. Indian economy has not only grown but transformed over the years. Though our economy is predominantly agro based, share of agricultural sectors in total gross domestic product (GDP) has declined over time. In 1980, share of agricultural sector in total GDP was at 34\% which declined to $16 \%$ in 2007-08 [2]. Between 2001 and 2011, country's total population increased by $1.7 \%$ annually, but urban population grew at a much faster rate of $3.18 \%$. Real per capita income also rose by $4.8 \%$ annually. During India's economic transformation, livestock sector has consistently contributed about $5 \%$ of total economic output. Between 1981 and
2006, livestock sector grew at rate of 3.9\% annually much faster than growth in crop sector, which grew by $2.8 \%$. Both crop and livestock sectors contributed to a growth rate of about $3 \%$ annually for agricultural value added during same period. In 2007-08, livestock sector contributed $26.5 \%$ to agriculture GDP, an increase from $14 \%$ in 1980-81 [2]. During 2009-10, the contribution of livestock sector to agricultural GDP was $29.64 \%$ [2].

Rajasthan is predominantly an agricultural state with an excellent potential for milk production. Dairy cooperatives have not only provided organized network of milk marketing to the rural households, but also provided the crucial technical inputs like provision of artificial insemination, health services and feed inputs. Cost plays an important role in portraying economic viability of a dairy enterprise. It is a critical economic indicator for milk producers, consumers and policy makers in order to provide an effective linkage between the milk producers and consumers for fixing the price of milk rationally. Generally, a milk producer can 
increase his dairy income in two ways either by increasing the milk production or by reducing cost of milk production. Cost of milk production often becomes a policy issue, when milk producers complain that the price of milk they are getting does not the cover cost of milk production. The present study was undertaken to work out economics of dairy farming on different size category basis.

\section{Methodology}

Jaipur district was selected purposively because it is second largest milk producer in the state (Department of Animal Husbandry, Jaipur, Rajasthan). Two tehsils were selected randomly and from each tehsil, a cluster of three villages having maximum number of commercial dairy farms were identified. To select a sample of commercial dairy farms, a complete enumeration of commercial dairy farms in these villages was done. The commercial dairy farms based on herd size were categorized into three size groups, namely small, medium and large using cumulative square root frequency method of stratification. Finally, 30 commercial dairy farms were selected on the basis of probability proportionate to the number of dairy farms in each category. Primary data on various aspects of milk production enterprises were collected from each of the selected dairy units by personal interview method.

\section{Capital investment}

The fixed investment on a commercial dairy farms comprised of investment on animals including milch animals, young stock and heifers, bulls and draft animals, investment on cattle shed and stores, machinery and equipments.

\section{Costs and returns concepts}

Fixed Cost: It includes interest on fixed capital and depreciation on animals, cattle sheds and machinery. Depreciation on fixed capital was worked out separately for milch animals, cattle shed, machinery and equipments keeping in view the present value and useful economic life of the capital asset.

Depreciation rate on milch animals was worked out as follows:

1. Cross- bred cows - 8 per cent (productive life 12.5 years),

2. Local cows and Buffaloes - 10 per cent (Productive life 10 years),

Depreciation rates on cattle shed, stores and dairy equipments were applied as under:

\begin{tabular}{|c|c|}
\hline Particulars & $\begin{array}{c}\text { Depreciation rate } \\
\text { per annum (\%) }\end{array}$ \\
\hline Pucca building & 2 \\
\hline Semi-pucca building & 5 \\
\hline Bullock cart & 10 \\
\hline Chaff cutter & 10 \\
\hline Milk cans and petty items & 20 \\
\hline
\end{tabular}

As the commercial dairy farm maintained animals of different species and age groups, to determine the relative share of fixed cost attributable to milch stock, the livestock maintained at the farm were converted into Standard Animal Units (SAU's) as per the methodology suggested by Patel RK., et al [3]. The fixed cost was apportioned on the basis of Standard Animal Units. The following relative weights were assigned.

\begin{tabular}{|l|c|}
\hline Animal & Standard Animal Units \\
\hline Local cow & 1.00 \\
\hline Crossbred cow & 1.40 \\
\hline Buffalo & 1.30 \\
\hline Crossbred heifer (> 1 year) & 0.75 \\
\hline Crossbred heifer ( $>$ 2 year) & 1.00 \\
\hline Buffalo/Local calves (> 1 year) & 0.50 \\
\hline Buffalo/Local heifer ( $>2$ year) & 0.75 \\
\hline Other calves (<1 year) & 0.33 \\
\hline
\end{tabular}

Variable costs: These costs include feed cost, labour cost, veterinary cost and other miscellaneous costs.

Feed cost: The cost incurred on green fodder, dry fodder and concentrate to feed the animals constituted feed cost. It was worked out by multiplying quantities of feeds and fodder consumed by animals with their respective prevailing prices. All the commercial farms adopted collective stall-feeding of their animals. To apportion the joint costs on feeds and fodder, standard animal units approach was applied.

Labour cost: It included family as well as paid hired labour. The hired labour was calculated considering time utilised in various dairy activities and wages paid. In case of family labour, the imputed value was taken as per the prevailing wage rate of permanent labour.

Veterinary cost: It included the cost incurred on natural service, artificial insemination (A.I.), vaccination, medicines and other charges/fees of veterinary doctors.

Miscellaneous costs: The cost of repairs, electricity, water charges, bucket, rope, etc was included in this group.

Total cost: It was obtained by adding all the cost components included in the fixed and variable costs, i.e.

Gross Cost $=$ Total Fixed Cost + Total Variable Cost

Net Cost: The nets cost was calculated by deducting the imputed value of dung, from the gross cost.

Cost per liter of milk production:

Net cost of maintenance per animal per day

Cost per Liter (Rs.) $=\frac{}{\text { Total milk produced per animal per day }}$ 


\section{Gross returns}

Gross Returns $=$ Quantity of milk * Market price of milk

Price of Milk: The price of milk differs according to type of milk and the season. The weighted average price of milk was calculated for each commercial farm as under:

Weighted average price $=\frac{\sum \mathrm{P}_{\mathrm{i}} * \mathrm{~W}_{\mathrm{i}}}{\Sigma \mathrm{W}_{\mathrm{i}}}$

Where,

$P_{i}=$ Price per liter of $i^{\text {th }}$ type of milk,

$\mathrm{W}_{\mathrm{i}}=$ Total quantity in volume of $\mathrm{i}^{\text {th }}$ type of milk sold by the farm.

Net returns: Net Returns $=$ Gross Returns - Net Cost

\section{Profitability}

The profitability of each category of farm was worked out on the basis of milk supplied to various agencies, milk retained at home and net returns over cost per liter of milk produced.

\section{Results and Discussion}

\section{Compound growth rate (CGR)}

Compound growth rates in production of milk in Rajasthan state and India are presented in table 1 . The table reveals that the milk registered a growth in production by 9.80 percent in Rajasthan and 9.97 percent in India. These growth rates were found significant at 1 percent level of significance.

\begin{tabular}{|c|c|c|}
\hline Year & Rajasthan & India \\
\hline $1997-98$ & 6487 & 72128 \\
\hline $1998-99$ & 6923 & 75424 \\
\hline $1999-00$ & 7280 & 78286 \\
\hline $2000-01$ & 7455 & 80607 \\
\hline $2001-02$ & 7758 & 84406 \\
\hline $2002-03$ & 7789 & 86159 \\
\hline $2003-04$ & 8054 & 88082 \\
\hline $2004-05$ & 8310 & 92484 \\
\hline $2005-06$ & 8713 & 97066 \\
\hline $2006-07$ & 10309 & 102580 \\
\hline $2007-08$ & 11377 & 107934 \\
\hline $2008-09$ & 11931 & 112183 \\
\hline $2009-10$ & 12330 & 116425 \\
\hline $2010-11$ & 13234 & 121848 \\
\hline $2011-12$ & 13512 & 127904 \\
\hline $2012-13$ & 13946 & 132431 \\
\hline CGR & 9.80 & 9.97 \\
\hline
\end{tabular}

Table 1: Total Milk Production in Rajasthan and India (000' tonnes).

Source: Department of Animal Husbandry, Dairying and Fisheries, Ministry of Agriculture, GoI [4].
The commercial dairy farms selected in each category are presented in the table 2. In small category, 15 dairy farms were selected out of 50 small dairy farms. In case of medium and large dairy farms, 10 and 5 dairy farms were selected respectively. The total number of selected commercial dairy farms was 30 out of 100 commercial dairy farms in the selected cluster.

\begin{tabular}{|l|c|c|}
\hline Category & $\begin{array}{c}\text { Total number of } \\
\text { commercial dairy farms }\end{array}$ & $\begin{array}{c}\text { Farms } \\
\text { selected }\end{array}$ \\
\hline $\begin{array}{l}\text { Small (10 to } 12 \text { milch } \\
\text { animals) }\end{array}$ & 50 & 15 \\
\hline $\begin{array}{l}\text { Medium (13 to 15 } \\
\text { milch animals) }\end{array}$ & 30 & 10 \\
\hline $\begin{array}{l}\text { Large (16 and above } \\
\text { milch animals) }\end{array}$ & 20 & 5 \\
\hline Total & 100 & 30 \\
\hline
\end{tabular}

Table 2: Selection of sampled commercial farms in jaipur district of rajasthan.

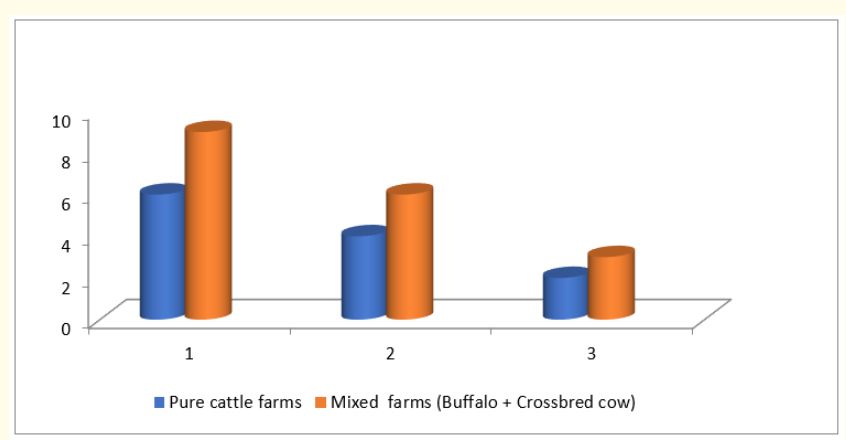

Figure 1: Type of dairy herd adopted on commercial dairy farms.

\section{Socio-economic status of the commercial farms}

The information relating to family size, educational status and land holding etc. of the dairy owners have been analysed and presented below in table 3 . The average size of family on sample commercial farms was 6.5 members. The average number of family members was maximum in medium farms (8) and lowest is in large farms (5) respectively. In case of educational status, the mean education scores were calculated. The mean education scores of the commercial dairy farm was lowest (3.54) in case of small category and highest (4.22) for medium category of sample dairy farms. The overall mean educational score was 2.5 . The average operational land holding for small, medium and large dairy farms was 2.35 hectares, 3.25 hectares and 8.27 hectares respectively. The proportion of operational land holding used for growing fodder was highest for large category (20.22\%) followed by medium $(18.17 \%)$ and small (14.25\%) farms. 


\begin{tabular}{|c|c|c|c|c|c|}
\hline Category & $\begin{array}{c}\text { Number of } \\
\text { farms }\end{array}$ & $\begin{array}{c}\text { Average } \\
\text { Family size }\end{array}$ & $\begin{array}{c}\text { Education status } \\
\text { of head of farm* }\end{array}$ & $\begin{array}{c}\text { Land holding } \\
\text { per farm (ha.) }\end{array}$ & $\begin{array}{c}\text { Percentage of area } \\
\text { allocated for fodder crops }\end{array}$ \\
\hline Small & 15 & 7.5 & 3.54 & 2.35 & 14.25 \\
\hline Medium & 10 & 8 & 4.22 & 3.25 & 18.17 \\
\hline Large & 5 & 5 & 2 & 8.27 & 20.22 \\
\hline Overall & 30 & 6.5 & 2.5 & 5.21 & 10.28 \\
\hline
\end{tabular}

Table 3: Category-wise family size, education status and land holdings of the sample commercial farms.

*Mean education score.

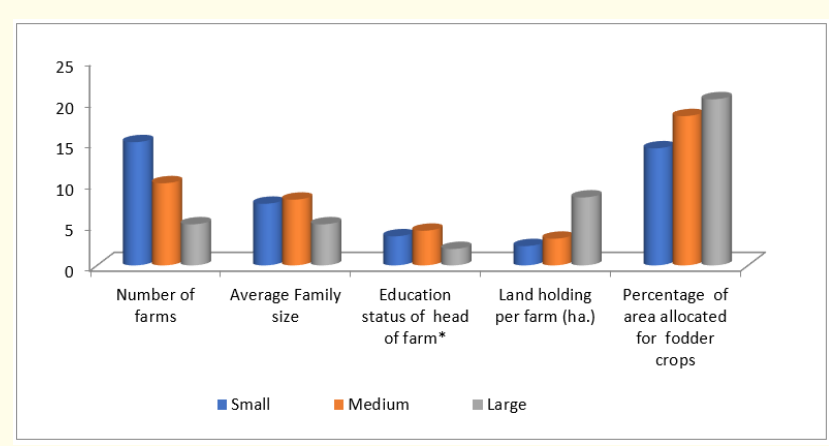

Figure 2: Category-wise family size, education status and land holdings of the sample commercial farms.

Type of the milch cattle adopted on the commercial farms is an important indicator of the preference of dairy owners of a particular region for a particular breed/species. Data regarding type of farm maintained on the sample commercial farms is presented in table 4 . These commercial farms have been classified as pure cattle farm and mixed cattle farms. The mixed farms were those commercial farms which kept a mix of cattle and buffaloes. It can be seen that, maximum farms were found to be mixed cattle farms $(60 \%)$ whereas pure cattle farms were $40 \%$.

\begin{tabular}{|l|c|c|c|c|}
\hline Description & Small & Medium & Large & Overall \\
\hline No. of commercial farms & 15 & 10 & 5 & $\begin{array}{c}30 \\
(100.00)\end{array}$ \\
\hline Farm Type & 6 & 4 & 2 & $\begin{array}{c}12 \\
(40.00)\end{array}$ \\
\hline Pure cattle farms & 9 & 6 & 3 & $\begin{array}{c}18 \\
(60.00)\end{array}$ \\
\hline $\begin{array}{l}\text { Mixed farms (Buffalo + } \\
\text { Crossbred cows) }\end{array}$ & 5 & 8 & 10 & 7.67 \\
\hline $\begin{array}{l}\text { Average milch animals } \\
\text { per farm }\end{array}$ & & & & \\
\hline
\end{tabular}

Table 4: Type of dairy herd adopted on commercial dairy farms.

*Figures in parentheses are the percentage to total investment
Level of investment reflects the extent of business activity and its income generating capacity in the long term. On the commercial dairy farms, fixed investment comprises of investment on animals, cattle shed and stores, machinery and equipments etc. The total capital investment on various heads across commercial dairy farms is presented in table 5 . The average capital investment per farm on sample commercial farms was found to be Rs 14.97 lacs indicating that commercial dairy farming is a highly capital intensive business. The dairy animals alone constituted nearly 61.15 percent of total investment followed by cattle shed (33.48\%). Machinery and equipments accounted for 5.36 per cent of the total investment in a commercial dairy farm. The table reveals that medium and large dairy farms invested maximum share of their fixed capital in the dairy animals whereas on the small dairy farms, relatively more investment was done on the development of infrastructure.

Cost and returns: Table 6 shows the cost and returns of sample dairy farms. The overall total cost of maintenance of cross- bred milch cattle on small category of sampled farm was estimated to be Rs. 314/animal/day. The variable cost was 88.21 per cent of the total cost. Cost of feed and fodder was the major cost component, which accounted for 29.29 percent of the total cost of maintenance. The average milk yield of cross-bred milch animal on small farms was found to be 15 liter/animal/day. The overall cost of production per liter of milk was found to be Rs. 25. As far as returns from the dairy animals are concerned, milch animal gave, an overall net return of Rs. 69/animal/day, whereas the net returns per liter of milk was Rs. 4.6. The total cost of maintenance of crossbred milch cattle on medium category of commercial farms was estimated to be Rs. 405/animal/day. The average milk yield of crossbred milch animals on medium farms was found to be 17 liter/day. The cost of milk production was worked out to be Rs. 23.24/liter. The average yield/milch animal on large farms was found to be 22 liter/day and the cost of milk production was worked out to be Rs.23.63/liter. On large dairy farms, each milch animal yielded an average net return of Rs. 140/animal/day. The study revealed that the net cost of milk production in case of cross-bred cows was highest on the large category of commercial farms and lowest in the small category. 


\begin{tabular}{|l|l|l|l|l|l|}
\hline Sr. No. & Items & \multicolumn{2}{|l|}{ Category of Commercial Farm } \\
\hline & & Small & Medium & Large & Overall \\
\hline (A) & Animals & & & & \\
\hline & (i) Milch animals & $350(40.22)$ & $787(52.92)$ & $1052(49.27)$ & $729.67(48.73)$ \\
\hline & (ii) Heifers & $35(4.02)$ & $68(4.57)$ & $145(6.79)$ & $82.67(5.52)$ \\
\hline & (iii)Calves & $18(2.06)$ & $29(1.95)$ & $51(2.38)$ & $32.67(2.18)$ \\
\hline & (iv)Draft animals & $47(5.40)$ & $68(4.57)$ & $97(4.54)$ & $70.67(4.71)$ \\
\hline & Total & $450(51.72)$ & $952(64.02)$ & $1345(62.99)$ & $915.67(61.15)$ \\
\hline (B) & Buildings & $358(41.15)$ & $457(30.73)$ & $689(32.27)$ & $501.33(33.48)$ \\
\hline (C) & Machinery and equipments & $62(7.12)$ & $78(5.24)$ & $101(4.73)$ & $80.33(5.36)$ \\
\hline & Total Investment (A+B+C) & $870(100.00)$ & $1487(100.00)$ & $2135(100.00)$ & $1497.33(100.00)$ \\
\hline
\end{tabular}

Table 5: Investment pattern on sample commercial dairy farms (000’ Rs/farm).

*Figures in parentheses are the percentage to total investment.S

\begin{tabular}{|c|c|c|c|c|c|c|}
\hline \multirow[b]{2}{*}{ Farm size } & \multicolumn{3}{|c|}{ Cross-bred cattle } & \multicolumn{3}{|l|}{ Buffalo } \\
\hline & Small & Medium & Large & Small & Medium & Large \\
\hline Green fodder & $30(9.55)$ & $42(10.37)$ & $57(10.71)$ & $35(9.53)$ & 47 (9.87) & $68(10.88)$ \\
\hline Dry fodder & $20(6.37)$ & $22(5.43)$ & $27(5.07)$ & $25(6.81)$ & $29(6.09)$ & $34(5.44)$ \\
\hline Concentrate & $42(13.37)$ & $56(13.82)$ & $69(12.96)$ & $50(13.62)$ & $66(13.86)$ & $80(12.80)$ \\
\hline Total feed cost & $92(29.29)$ & $120(29.62)$ & $153(28.75)$ & $110(29.97)$ & $142(29.83)$ & $182(29.12)$ \\
\hline Labour & $56(17.83)$ & $70(17.28)$ & $82(15.41)$ & $60(16.34)$ & 77 (16.17) & $98(15.68)$ \\
\hline Veterinary & $27(8.59)$ & $38(9.38)$ & $46(8.64)$ & $30(8.17)$ & $40(8.40)$ & $50(8.00)$ \\
\hline Miscellaneous & $10(3.18)$ & $15(3.70)$ & $25(4.69)$ & $15(4.08)$ & $20(4.20)$ & $28(4.48)$ \\
\hline Total Variable Cost & $277(88.21)$ & $363(89.62)$ & 459 (86.27) & $325(88.55)$ & $421(88.44)$ & $540(86.40)$ \\
\hline Depreciation on fixed assets & $17(5.41)$ & $20(4.93)$ & $38(7.14)$ & $18(4.90)$ & $26(5.46)$ & $45(7.20)$ \\
\hline Interest on fixed capital & $20(6.36)$ & $22(5.43)$ & $35(6.57)$ & $24(6.53)$ & $29(6.09)$ & $40(6.40)$ \\
\hline Total Cost & $314(100.00)$ & $405(100.00)$ & $532(100.00)$ & $367(100.00)$ & $476(100.00)$ & $625(100.00)$ \\
\hline Value of dung & 8 & 10 & 12 & 7 & 9 & 12 \\
\hline Net Cost & 306 & 395 & 520 & 360 & 467 & 613 \\
\hline Sale price of milk (Rs./liter) & 25 & 28 & 30 & 27 & 30 & 32 \\
\hline Milk production (liter) & 15 & 17 & 22 & 18 & 20 & 24 \\
\hline Gross return & 375 & 476 & 660 & 486 & 600 & 768 \\
\hline Net Return & 69 & 81 & 140 & 126 & 133 & 155 \\
\hline Cost per liter of milk (Rs./liter) & 20.40 & 23.24 & 23.63 & 20 & 23.35 & 25.54 \\
\hline Net Returns per liter (Rs./liter/ & 4.60 & 4.76 & 6.36 & 7 & 6.65 & 6.45 \\
\hline Animal/day) & & & & & & \\
\hline
\end{tabular}

Table 6: Cost and Returns per Animal per day on different categories of commercial dairy farms (Rs/Animal/day).

Total cost of maintenance of milch buffalo on large dairy farms was Rs.625/animal/day in which variable costs accounted for about 86.40 per cent of the total cost. However, due to a significant number of animals gone dry at these farms the average milk productivity/milch animal turned out to lower causing milk production cost to escalate to Rs 25.54/liter. Returns from the buffaloes on large commercial farms showed that each milch buffalo earned overall net return of Rs 6.45/liter/day. Returns from the buffaloes on small and medium dairy farms showed that each milch buffalo earned overall net return of Rs 7and Rs 6.65/liter/day 
which was higher than that of large dairy farms. This may be due to more efficient management of small and medium dairy farms.

To work out category wise profitability/farm/annum on dairy farms, cost and returns were worked out on per annum basis which are presented in table 7. It may be observed that small category of dairy farms generated a net surplus of Rs 267180 per year whereas the medium dairy farms earned Rs 412085 . The large dairy farms earned net profit of Rs. 946445 per year. All the farms were found to be financially viable [5-9].

\begin{tabular}{|c|c|c|c|c|c|}
\hline Category & $\begin{array}{c}\text { No. of } \\
\text { farms }\end{array}$ & $\begin{array}{c}\text { Total cost/day/ } \\
\text { farm (Rs) }\end{array}$ & Revenue (Rs) & $\begin{array}{c}\text { Net Income/day/ } \\
\text { farm (Rs) }\end{array}$ & $\begin{array}{c}\text { Net income per farm } \\
\text { per year (Rs) }\end{array}$ \\
\hline Small & 15 & 1725 & 2457 & 732 & 267180 \\
\hline Medium & 10 & 2458 & 3587 & 1129 & 412085 \\
\hline Large & 5 & 5248 & 7841 & 2593 & 946445 \\
\hline
\end{tabular}

Table 7: Cost and Returns per farm per annum on different categories of dairy farms.

\section{Conclusion}

Compound growth rates in production of milk in Rajasthan state and India registered growth in production by 9.80 percent and 9.97percent respectively. The average capital investment per farm on sample dairy farms was found to be Rs 14.97 lacs indicating that commercial dairy farming is a highly capital intensive business. The dairy animals alone constituted nearly 61.15 percent of total investment followed by cattle shed (33.48\%). Machinery and equipments accounted for 5.36 per cent of the total investment on a commercial dairy farm. The total cost of maintenance of crossbred milch cattle on medium category of commercial farms was estimated to be Rs. 405/animal/day. The average milk yield of crossbred milch animals on medium farms was found to be 17 liter/ day. The cost of milk production was worked out to be Rs. 23.24/ liter. The average yield/milch animal on large farms was found to be 22 liter/day and the cost of milk production was worked out to be Rs.23.63/liter. Returns from the buffaloes on small and medium dairy farms showed that each milch buffalo earned overall net return of Rs 7 and Rs 6.65/liter/day which was higher than that of large dairy farms. It may be observed that small category of dairy farms generated a net surplus of Rs 267180 per year whereas the medium dairy farms earned Rs 412085 . The large dairy farms earned net profit of Rs. 946445 per year.

\section{Bibliography}

1. FAO. FAOSTAT. Rome: Food and Agriculture Organization of the United Nations (2008).

2. GOI. Department of Consumer Affairs (2002-2008).

3. Patel RK., et al. "Standardization of Bovine Units". Indian Journal of Animal Health 93.2 (1983): 457-550.
4. Government of India Basic Animal Husbandry Statistics. AHS Series 12, New Delhi: Ministry of Agriculture. Department of Animal husbandry Dairying and Fisheries, Krishi Bhavan, New Delhi (2010).

5. Ashalatha P., et al. "Impact of dairy cooperatives on the milk production, consumption and marketed surplus pattern on the members". Indian Journal of Dairy Science 57 (2004): 6064.

6. Chand K., et al. "Economic Analysis of Commercial Dairy Herds in Arid Region of Rajasthan". Indian Journal of Agricultural Economics 57 (2002): 224-233.

7. Government of India Economic Survey 2011-12, New Delhi: Ministry of Finance, Economic Division (2010): 194.

8. Singh R., et al. "Economic analysis of milk production in tribal area of Udaipur (Rajasthan)". Indian Journal of Dairy Science 59.5 (2006): 328-336.

9. Sirohi S., et al "Economics of milk production: variations across productivity level”. Indian Journal of Dairy Science 60.2 (2007): 124-128.

\section{Volume 3 Issue 7 July 2019}

(C) All rights are reserved by Shirish Sharma. 